Pre-publication version of article accepted for publication in the Journal of Ethnic and Racial Studies (2016)

\title{
On the Threshold of Statelessness: \\ Palestinian narratives of loss and erasure
}

\author{
Elena Fiddian-Qasmiyeh \\ University College London \\ e.fiddian-qasmiyeh@ucl.ac.uk
}

\begin{abstract}
This article examines how Palestinians in France, Sweden and the UK negotiate, mobilise and/or resist, and ultimately problematise, notions of statelessness as a concept and as a marker of identity. Centralising Palestinians' conceptualisations in this manner including accounts which directly challenge academics' and policy-makers' definitions of the problem of, and solution to, statelessness - is particularly important given that statelessness emerges as both a condition and a label which erase the ability to speak, and be heard. The article draws on the narratives of 46 Palestinians to examine perceptions of statelessness as a marker of rightlessess, home(land)lessness and voicelessness. It then explores statelessness through the paradigm of the 'threshold', reflecting both on interviewees' ambiguity towards this label, status and condition, and the extent to which even Palestinians who hold citizenship remain 'on the threshold of statelessness'. It concludes by reflecting on interviewees' rejection of a label which is imposed upon them 'from a distance' via bureaucratic processes which reproduce, rather than redress, processes of erasure and dispossession.
\end{abstract}

Keywords: belonging, dispossession, identity, resistance, voice

\section{INTRODUCTION}

Statelessness - the condition of holding no nationality and therefore being without the protection of a state - has been 'rediscovered' by academics, policy-makers and practitioners since the 2000s (Van Waas 2008; Edwards and Van Waas 2014). In part, this is related to the $60^{\text {th }}$ anniversary of the 1961 Convention on the Reduction of Statelessness and the $50^{\text {th }}$ anniversary of the 1954 Convention Relating to the Status of Stateless Persons in 2011 and 2014 respectively. Advocacy campaigns and policy reports related to these anniversaries - including numerous Mapping Statelessness reports, the 2014 First Global Forum on Statelessness and the United Nations High Commissioner for Refugees' 2014 I Belong campaign - have highlighted the extent to which statelessness is effectively synonymous with individual and collective vulnerability to marginalization and human rights abuses, asserting that there is an urgent need to 'solve' situations of statelessness. In particular, the United Nations, NGOs and government ministries recognise that the main 'solution' is for stateless people to secure a nationality and state protection from their country of origin or their country of habitual residence (UNHCR 2014). To achieve this 'solution', and to prevent future cases of statelessness, states should become signatories to the above-mentioned Conventions, implement appropriate reforms to their nationality laws and/or apply their existing laws without discrimination, and establish statelessness determination procedures if they do not yet 
Pre-publication version of article accepted for publication in the Journal of Ethnic and Racial Studies (2016)

exist in order to identity stateless people (ibid).

Stateless people's experiences of rightlessness and vulnerability have thus now been extensively acknowledged, and a range of mechanisms have been promoted to secure legal redress, including through 'identification' procedures. However, precisely how individuals and groups who are defined in these terms by academics, policy-makers and practitioners themselves engage with, experience, accept and/or reject such labels and policy categories remains under-examined to date. This is in direct contrast to analyses conducted within the related field of Refugee and Forced Migration Studies (i.e. Zetter 1991, 1997; Gupte and Mehta 2007; Ludwig 2013). Inter alia, these argue that asylumseekers strive to be recognised as refugees in order to obtain international protection and opportunities for resettlement to a country in the global North, and yet certain groups may simultaneously reject the 'refugee label' as an imposed bureaucratic category charged with stigmatizing and insulting connotations which constitute them as "stupid, misfits, ignorant, poor and uncivilized" (Kumsa 2006: 242).

In many regards, it is unsurprising that there are no such studies vis-à-vis 'the stateless label' given that "the study of statelessness emerged as the study of nationality law" (Manly and van Waas 2014:5) and the majority of academic literature on statelessness has subsequently primarily been developed from the perspective of international law (ibid). Indeed, it is only recently that a space has emerged in academia for personal and political reflections on this label to complement, and at times challenge, the official discourses developed by academics and policy-makers (Redclift 2013; Fiddian-Qasmiyeh 2014).

In addition to the relationship between 'statelessness studies' and nationality law, the rediscovery of the concept and legal category of statelessness is also often historically situated vis-à-vis Hannah Arendt's denunciation of this condition as the very absence of the "right to have rights" (1951); related studies correspondingly explore the relationship between statelessness and political exclusion and inclusion from the perspective of political theory (cf. Staples 2012:14-15). Such an approach has itself been critiqued by those, such as Rancière (2004:299), who argue that Arendt's theorisation of statelessness provides "a frame of description and a line of argumentation that later would prove quite effective for depoliticizing matters of power and repression and setting them in a sphere of exceptionality that is no longer political, in an anthropological sphere of sacrality situated beyond the reach of political dissensus." In effect, as noted by Vali (1998:85),

In the political discourse of modernity, statelessness is conceived as a humanitarian issue, evoking compassion and mercy, on a par with famine, hunger and homelessness. This is because a consideration of statelessness as politics and the stateless as a 'political subject' immediately invokes the thorny issue of rights, which in the political discourse of modernity, is intrinsically linked with the institution of the nation-state and national sovereignty.

'Vulnerable' stateless people are therefore constituted as ideal victims who are to be supported by modern global campaigns to fulfill their 'belonging' in the world - to return 
Pre-publication version of article accepted for publication in the Journal of Ethnic and Racial Studies (2016)

them to a sphere where they have 'the right to have rights'. In contrast, the stateless person as a 'political subject' demanding not only individual but collective, and indeed national, rights, defining the terms of their own inclusion or exclusion from international debates and agendas, or determining the meaning(s) which statelessness may or may not have for them on individual and collective levels, has been placed on the margins of this paradigm.

This article addresses these lacunae by drawing on the narratives of 45 Palestinians interviewed in France, Sweden and the United Kingdom between 2012 and 2014, to examine how they negotiate, mobilise and/or resist, and ultimately problematise, notions of statelessness as a concept and as a marker of identity. Drawing on these narratives, the paper thus transcends the focus on documenting the 'lived experiences' of statelessness as personal experiences of vulnerability - which has been critiqued for reducing stateless people to apolitical victims on the margins of politics and of the polis (op cit) - by examining how research participants conceptualise statelessness on abstract, personal and political levels alike. Centralising the voices of Palestinians in this way - including accounts which directly challenge the ways in which academics and policy-makers have defined the problem of, and solution to, statelessness - is particularly important given the extent to which statelessness is itself understood as both a condition and a label which erase the ability to speak, and be heard.

\section{Methodological Note}

This paper forms part of a broader comparative project funded by the Leverhulme Trust, which aims to reconceptualise individual and collective meanings of statelessness from the perspectives of EU-based Roma, Kurds and Palestinians - as three groups which for a variety of historical reasons have no independent and internationally-recognised state of their own. ${ }^{i}$ Inter alia, the broader project analyses the ways in which Palestinians and Kurds who hold a wide diversity of legal statuses in the EU conceptualise connections with other members of 'their' communities across time and space, and socio-political commitments to their respective homelands in the Middle East (Fiddian-Qasmiyeh, 2014).

The research aimed to capture the heterogeneity of Palestinians in Europe, with interviewees consisting of 27 men and 18 women aged between 18 and 70. Interviewees had arrived in France, Sweden or the UK between 1973 and 2012, and held a wide range of legal statuses in these countries at the time of interview.

\begin{tabular}{|l|l|l|l|}
\hline UK $(\mathbf{N}=14)$ & Sweden $(\mathbf{N}=\mathbf{1 0})$ & France $(\mathbf{N}=\mathbf{2 1})$ & Total $(\mathbf{N}=\mathbf{4 5})$ \\
\hline $\begin{array}{l}\text { 11 British } \\
\text { citizenship }\end{array}$ & 10 Swedish citizenship & $\begin{array}{l}\text { 10 French nationality } \\
\text { 2 Refugee Status }\end{array}$ & 35 Citizen \\
1 Refugee status & & 3 Stateless Status & 3 Stateless \\
1 Palestinian & 2 Israeli citizenship, 1 & 2 Palestinian \\
passport & on student visa & passport holder \\
1 US citizenship on & & 2 Temporary & 2 Temporary \\
student visa & residency & resident \\
\hline
\end{tabular}


Pre-publication version of article accepted for publication in the Journal of Ethnic and Racial Studies (2016)

\begin{tabular}{|l|l|l|l|}
\hline & $\begin{array}{l}\text { 1 Palestinian passport } \\
\text { on student visa }\end{array}$ & \\
\hline
\end{tabular}

Figure 1. Legal statuses held by research participants at the time of interview

Indeed, France, Sweden and the UK were selected as the core field-sites for this project both in light of Palestinians' diverse migration histories and trajectories to different EU states, but also in order to examine how the different migration and citizenship regimes in these countries inform interviewees' conceptualizations of statelessness. Of particular relevance for this article, and as explored below, France has a well-established statelessness determination procedure implemented by the Office Francais de Protection des Réfugiés et Apatrides (OFPRA), which explains why the interviewees who held official stateless status at the time of research were all interviewed in France. In contrast, no interviewees held (or had formerly held) stateless status in the UK, since that country only introduced a formal statelessness determination process in April 2013. In turn, all interviewees in Sweden were Swedish citizens, which many interviewees argued should be viewed in light of Sweden having historically offered a more expedited mechanism to secure citizenship than those processes available through either the UK's or France's immigration and citizenship regimes.

Although four interviewees were born in Europe to (one or both) Palestinian parents, the interviewees' current and former legal status(es) in Europe partly depended on the 'home' context across the Middle East and North Africa (MENA) from which they and their families had migrated. Interviewees' wide-ranging points of origin correlated not only with the diverse legal statuses they had held in MENA before arriving in the EU, but also their means of entering and remaining in France, Sweden or the UK. For instance, those interviewees who had been registered with the United Nations Relief and Works Agency for Palestine Refugees in the Near East (UNRWA) as Palestine refugees in Lebanon, Syria and Jordan typically applied for asylum or stateless status upon arrival in the EU, while a number of the interviewees who held Palestinian passports or were Palestinian-Arab citizens of Israel had been able to secure student or work visas to enter and/or remain in the EU. In all countries, a small number of interviewees had married European citizens and had been naturalised after the relevant residence requirements had been met. Ultimately, interviewees' experiences and understandings of statelessness were influenced in different ways both by these pre-existing and evolving legal statuses, and by the conditions under which they and their families had lived in the MENA region before arriving in the EU.

\section{PALESTINIANS' STATELESSNESS AND RE-STATING THE RIGHT TO SELF- DETERMINATION}

UNHCR has an 'international' mandate vis-à-vis refugees, and yet Palestinian refugees have historically been excluded from its remit due to Article 1(d) of the 1951 Geneva Convention Relating to the Status of Refugees, which specifies that "This Convention shall not apply to persons who are at present receiving from organs or agencies of the United Nations other than the [UNHCR] protection or assistance.” The only UN agency to which this pertains is UNRWA, which provides assistance (but not protection) to the 
Pre-publication version of article accepted for publication in the Journal of Ethnic and Racial Studies (2016)

majority of Palestinians in the Middle East. As a result, although Palestinians are registered as 'Palestine refugees' within UNRWA's five areas of operation (Gaza, the West Bank, Lebanon, Jordan and Syria), they have largely been excluded from the 'international refugee regime' (Akram, 2014). Unable to benefit from the services and protection of UNHCR in the Middle East, Palestinians have also often been excluded from refugee status determination procedures in the global North due a mis-application of Article 1(d), and they have also typically remained invisible in global statistics vis-à-vis forced migration. With Palestinian refugees often framed as 'exceptions' from the international 'refugee norm', this leads us to consider to what extent Palestinians are conceptualized as being stateless by UNHCR (and international law), before turning to the perspectives of Palestinian interviewees themselves.

In light of the above, it is perhaps unsurprising that the 5 million Palestinians who are stateless under international law were nonetheless excluded in 2014 from UNHCR's ' $I$ Belong' campaign and its 'global' statistics on statelessness. This decision was justified by the UN High Commissioner for Refugees on the basis that the Palestinian State has been recognized by the UN General Assembly and that the solution to Palestinians' statelessness is the implementation of appropriate nationality laws, denominating this a "very specific situation" requiring a "political solution” (Guterres in Larson, 2014).

Palestinians' statelessness does indeed require a "political solution," and yet categorizing it as a "very specific situation" reiterates the extent to which Palestinians 'do not belong,' but continue to be positioned as 'exceptions' to be excluded from the international statelessness agenda. Furthermore, positing that the Palestinian context requires a "political solution" depoliticises other contexts of statelessness by suggesting that these can readily be addressed through apolitical technical and legal mechanisms (FiddianQasmiyeh, 2014).

UNHCR's decision to exclude Palestinians from its campaign and statistics has been criticised by the Institute of Statelessness and Inclusion (ISI, 2014), which has noted that, although not all Palestinians necessarily fall under UNHCR's statelessness protection mandate, a large proportion at present are, and an unknown number in future will be, under UNHCR's mandate even after Palestine is fully recognised as a State, its territorial borders and territorial sovereignty have been determined, and its national legislation has been implemented. As such, the Institute calls upon UNHCR to recognise its obligations towards these Palestinians in the present and future, rather than reproducing their exclusion from the international protection regime.

The contours of the question of statelessness in the Palestinian context were expounded by a leading UNHCR official interviewed for this project, who started by identifying the emergence of the state of Israel as being at the root of Palestinians' protracted refugeedom, before discussing the relationship between the absence of the Palestinian state and Palestinians' ongoing statelessness:

Palestine is a situation of state succession ... the creation of the state of Israel, and the implementation of the Israeli nationality law to certain populations but not 
Pre-publication version of article accepted for publication in the Journal of Ethnic and Racial Studies (2016)

others, has resulted in the fact that [Palestinians] have become refugees... UN resolutions are very clear about the creation of two states, Israel and Palestine. [However], despite the international community's efforts, Palestine does not have the full status of a state. For now, those people are without a state since the state does not exist... Juridically, they could potentially become citizens of a state or nationals of a state but that [Palestinian] state does not exist yet with all of its prerogatives and so they are in a situation of statelessness....

Interview, France, 2012

Identifying the establishment of an independent Palestinian state as a prerequisite to the solution of Palestinians' statelessness, the UNHCR official further clarified that "the entire role of the United Nations is to help ensure that these people no longer be stateless and become nationals of the Palestinian state". The international community therefore has a clear obligation to assist Palestinians to become Palestinian nationals, even when the "juridical" possibility of Palestinians becoming citizens or nationals of a second state exists.

The complex relationship between the granting of non-Palestinian nationality/citizenship and Palestinians' Right of Return - a right enshrined in UN Resolutions 194 and $3236^{\mathrm{ii}}$ has been central to debates regarding the fair and just treatment of Palestinians across the Middle East since the 1950, with most MENA states, the Palestinian Authority, and many Palestinian political factions holding that granting a non-Palestinian nationality to Palestinian individuals, families and collectives would weaken the Right of Return. As maintained by the above-cited UNHCR representative, although a large proportion of the 5 million Palestinians in the region are de jure stateless, ${ }^{\text {iii }}$ "this does not mean that all Palestinians are necessarily stateless because a number of them as you know, in Jordan, have received Jordanian nationality" (emphasis added). When asked to clarify whether, officially, Palestinians who hold Jordanian and Israeli nationality would no longer be considered to be stateless, he answered

Yes... [and] there are many more because there are French Palestinians, American [Palestinians]... whole groups of people who become [nationals], thanks to the laws in the country in which they are living... If a Palestinian child, a Palestinian refugee is born in the US, well he automatically acquires American nationality, for example. So there is a whole group of Palestinians who are not stateless, those in Jordan, those in Israel, and of course, those who are in many countries around the world of which they have acquired the nationality.

Emphasis added.

Of particular relevance for the remainder of this paper is the way in which statelessness is conceptualized by different actors in light of the apparent disconnect between the international community's obligation to assist Palestinians to become Palestinian nationals, and the assumption that "of course," those who have acquired the nationality of a second or third country are no longer stateless. While it is clear that "Nationality Matters' ${ }^{\text {iv }}$ in so far as granting 'a' nationality 'resolves' de jure statelessness, the remainder of this article examines how Palestinian interviewees conceptualise their status 
Pre-publication version of article accepted for publication in the Journal of Ethnic and Racial Studies (2016)

and statelessness both in the Middle East and in the European diaspora. In particular, it examines their perceptions of statelessness as a marker of rightlessness,

home(land)lessness and voicelessness which is simultaneously embraced and yet resisted as an ambiguous label, status and condition imposed upon them through a range of political and bureaucratic processes.

\section{Marking Rightless, Home(land)less and Voiceless}

In many regards, interviewees' narratives echo the three losses resulting from statelessness traced by Arendt: the loss of home (exile), the loss of state protection (basic rights), and the absence of a place in the world (political rights). Their accounts therefore highlight not only the vulnerability faced by Palestinians precisely due to the lack of state protection and the inability to seek one's basic and political rights, but also centralize the loss of home and homeland. This is particularly significant given that literature pertaining to statelessness rarely acknowledges that the homeland - which has remained central to conceptualisations and theorisations of diasporic identity - is often as central to understandings of statelessness, and at times even more so, than the loss of the state or nationality.

With regards to the paradigm of rightlessness, 70-year-old Abbas Shiblak, who was born in Haifa and has written extensively on statelessness in the MENA region (ie Shiblak 1996), summarized the socio-legal implications of being stateless as follows: "You are no-one. It's like a ship with no flag. You are not protected. You are exposed" (interview, UK, 2013). Likewise, 63-year-old Ahmed, who was born in Umm Khalid, equated statelessness with being a "zero": "you do not have an identity, a personality, an existence" (interview, Sweden, 2014). In his interview, Ahmed continued to explore the dual characteristics of lacking an identity and protection, by arguing that:

An orphan is better than a stateless person because you do not exist if you do not have a state. An orphan might have relatives that can take care of them but nobody embraces us. If you are stateless, it is like when nobody asks you if you are sick, hungry or thirsty. But when you have a state, you belong to a state that can care about you.

The essence of being without state protection was further encapsulated by UK-based Jibril, who recounted his experiences of statelessness through the dual tropes of being unable to speak and of being inaudible. He explained his experiences of the latter by virtue of having no diplomatic representative to speak on his behalf: while the voice of his Italian-born wife was magnified by summoning her Ambassador to assist the couple when they were prevented from crossing an international border at a Spanish airport, Jibril has no nationality and, by extension, no voice. His statelessness was effectively interpellated by proxy, since at the moment that his wife's 'presence' and audibility as a citizen was reinforced through this encounter at/through the border, so too was Jibril's 'absence' marked (40-year-old born in a refugee camp in Jordan; interview, UK, 2013).

These accounts of disenfranchisement thus echo two key absences: having no state to 'project' your voice, and simultaneously having no home in the world and thereby being unable to enjoy basic rights. The interconnected experiences of voicelessness and 
Pre-publication version of article accepted for publication in the Journal of Ethnic and Racial Studies (2016)

homelessness were also central to Laith's understanding of statelessness:

Being homeless, in a way. Homeless on a global scale. Not having an obvious place where you can seek your rights. In today's political situation, states provide a voice to people. States are responsible for giving basic rights to people. So [statelessness is] having no place to claim those rights... On a collective level, people want to have a voice. And having a state, not being stateless, projects that voice.

21-year-old born in Nablus. Interview, UK, 2013

These references to voicelessness do not mean to say that individuals cannot speak, but rather that the support of a state is needed for this voice to be "projected" and heard by Others; having a voice, Laith asserted, ultimately means not only expressing an opinion, but "Being able to enact change", to change "something that I do not think is fair."

Agreeing with the assertion that being stateless means that people are unable to change their lives or claim their rights, Miriyam - a 42-year-old born in Nazareth - posited that:

Not having your own homeland, your own state, is to be subjected to others' mercy, to be subjected to others' ferocity ... You can't create the future that you want, so you don't live life to its fullest...

Interview, France, 2012

Just as Ahmed and Laith drew attention to the absence of an internationally-recognised Palestinian state and of being 'homeless', Miriyam also argued that stateless people are unable to make decisions about their own future, and are "subjected to others' mercy" or "ferocity," simultaneously because of the absence of the Palestinian state and the absence of the Palestinian homeland.

In their accounts, statelessness is thus simultaneously a legal, a political, and an existential condition. Although legal definitions of statelessness centralise nationality and state protection, interviewees such as Laith and Miriyam presented the Palestinian homeland - one of the key defining features in understandings of diasporic identity - as being as important to their understanding of statelessness, and at times even more important, than the absence of a nationality and state protection. Importantly, Ahmed, Jibril, Laith and Miriyam all identified themselves as stateless even though they hold one or more nationalities: for instance, Laith is a British citizen who also holds a Palestinian passport and a West Bank identity document, and Miriyam has both Israeli nationality and French citizenship. Legally speaking, they are not classified as 'stateless people' in the EU given that they are citizens, and yet they consider themselves to 'be' stateless on a collective level.

By highlighting the multiple dimensions of statelessness, including the lack of rights and state protection, but also the sense of being home(land)less and voiceless, they continue to identify themselves as stateless. They therefore challenge policy-makers' assumptions that being granted 'a' nationality is the official solution to statelessness. Likewise, 25- 
Pre-publication version of article accepted for publication in the Journal of Ethnic and Racial Studies (2016)

year-old Paris-born Mahmoud argued that all Palestinians in the world are stateless, whether they hold 'a' nationality or not: "Simply from the fact of being Palestinian...we know we are apatride. We are a people without a homeland (sans patrie). We would like to be reunited with our homeland (retrouver notre patrie)..." (interview, France, 2012). In his view, Palestinians' statelessness cannot be 'solved' by granting 'a' nationality since the relationship with the Palestinian homeland ${ }^{\mathrm{V}}$ remains a contested one; rather, statelessness will only be resolved when a specific state (Palestine) grants a specific (Palestinian) nationality. Through this concise statement, Mahmoud thereby directly equates Palestinian-ness with being stateless in the sense of being separated from the homeland, even when holding one of more citizenships. ${ }^{\mathrm{vi}}$

\section{On the Threshold of Statelessness}

A further dimension disrupting the assumption that holding 'a' nationality necessarily resolves statelessness is grounded in Palestinians' experiences of nationality being fraught with insecurity, rather than offering security. For instance, Palestinians who held Jordanian nationality have repeatedly been stripped of their nationality and rendered stateless once again (HRW 2010), and Molavi refers to the dual policies of exclusion and inclusion that constitute Palestinian citizens of Israel as "stateless citizens" (2013). Through a process of what we can understand as 'travelling fear' (following Said, 1983:226-247; also Fiddian-Qasmiyeh 2013), Marwa - a 30-year-old born in a refugee camp in Syria - referred to the constant fear of being stripped of one's nationality, a fear that has travelled with her from the Middle East to Europe: "The fear becomes part of your identity because wherever you go, you are not fully accepted. Sweden can today be the perfect partner but still there is a fear that this relationship can change and end" (interview, Sweden, 2014). The potential for expulsion from the country that has granted you nationality whilst hosting you as a guest was also stressed by 33 -year-old Faisal, who was born in a refugee camp in Lebanon; he was concerned that there was no "guarantee that the next president or government will not do the same thing as previous governments... Palestinians probably think that Sweden can one day have a racist government and can deport them" (interview, Sweden, 2014). This resonates clearly with the concept hostipitality so astutely theorised by Derrida (2000), highlighting that "hospitality" is always "parasitized by its opposite, 'hostility', the undesirable guest which it harbours as the self-contradiction within its own body" (ibid:3). As such, hospitality itself inherently bears "its opposite" but also its own opposition, the everpresent possibility of hostility towards the Other who has, at one time, been welcomed at the threshold, and yet, "Perhaps no one welcomed is ever completely welcome" (ibid:6; see Fiddian-Qasmiyeh, 2015:109). Interviewees' fears and all they represent suggest that even when holding 'a' citizenship, many Palestinians continue to be on, or to embody, what I refer to as 'the threshold of statelessness' (also Qasmiyeh 2014).

However, as a zone within which "we witness a constant shifting from one condition to another, neither of which is definable once and for all" (Vighi et al 2014:viii), the threshold also captures the ambivalence expressed by those interviewees such as Feiruz, an 18-year-old born in Gaza who did not identify with the term 'stateless' on either personal or political levels, and yet continued to recognise themselves as simultaneously stateless and not stateless: 
Pre-publication version of article accepted for publication in the Journal of Ethnic and Racial Studies (2016)

When I think about statelessness, what comes to mind is being without rights and being deprived of my homeland. I understand that we Palestinians are stateless because we were expelled from our homeland but that is different from saying that I do not have any homeland at all since we still have Palestine. I am both stateless and not stateless.

Interview, Sweden, 2014. Emphasis added

Recognizing that their expulsion and dispossession from Palestine have rendered them stateless, Feiruz nonetheless resists the term precisely because it denotes the absence of a homeland whose existence she asserts. This resistance does not result in an absolute rejection of either 'being' or 'not being', but rather is expressed through a form of "complementarity" (Vighi et al, 2014:ix) which "includes both these conditions within its own space" (ibid:viii): simultaneously a citizen and a stateless person; both with(in) and without Palestine; a cipher who is both no-one and some-one.

Whilst echoing this ambivalence, Mahmoud redefined the terms of complementarity in order to transcend the binary represented by this overlapping rejection and acceptance of the label and condition of statelessness. On the one hand, he asserted that "I don't really consider myself to be stateless. Because to consider myself as such would really mean that we have lost the struggle, [that] the country doesn't really exist any more, that there really isn't any hope for return," and yet, "as a matter of fact, yes, I am stateless." However, ascribing to this status is only imaginable for Mahmoud if statelessness is itself redefined to centralise the continued "connection to Palestine":

In our case the term stateless should mean that we are not on our land... what matters is the relationship to the land. Where one comes from. We are stateless because we are not on our land of origin and not because our state did not emerge after the carving up done by the League of Nations.

Interview, France, 2012. Emphasis added

This explicitly entails re-territorialising statelessness, demanding that this marker and process be recognised as reflecting neither the loss of an erased land nor the failed emergence of a state, but rather the ongoing resistance to the collective dispossession from the Palestinian homeland. This re-territorialisation of statelessness provides a reconfiguration both of space and time, and the corresponding reinscription of Palestinians in both of these (also Sanbar 2001:91-92).

However, if Mahmoud and Fatima represent the threshold through the paradigm of "complementarity rather than opposition" (Vighi et al 2014:ix), with Mahmoud reconstituting the contours of that which is inside and outside of the very signifier 'stateless,' other interviewees such as Kanaan reject the applicability or validity of this concept by reasserting the spatial and temporal specificity of the Palestinian threshold:

I cannot accept the thought that we Palestinians are stateless... I know where my homeland is. We will claim it back. When, is another question... It is impossible for me to feel that I am stateless. I have never used the word stateless for myself. 
Pre-publication version of article accepted for publication in the Journal of Ethnic and Racial Studies (2016)

28-year-old born in Germany. Interview, Sweden, 2014

Kanaan thus opposes the discourse that constitutes Palestinians as quintessentially stateless since they have neither a state nor a homeland, precisely by asserting the presence (from a distance) of Palestine in the past, present and future, thereby contesting the processes which have erased Palestinians from time and space:

By departing from space, the Palestinians, about whom the whole world agreed to say 'they do not exist', also departed from time. Their history and their past were denied. Their aspirations and their future were forbidden... Driven out of time and space, the Palestinians would ultimately see themselves as deprived of the right to their own name.

Sanbar 2001:91-92

The very denomination of a loss, or absence of a place in the world was rejected by other interviewees such as Sara and Saif, who were both born in refugee camps in Lebanon and were interviewed respectively in France and Sweden: 53-year-old Sara argued that the term stateless is itself "unjust because one cannot be 'apatride.' One still belongs to a place!" and 43-year-old Saif questioned its validity "because everyone comes from somewhere. Everyone has their roots somewhere." Sara not only asserted that it was unjust, but also incorrect to use this term, stating that the word apatride itself "is not properly described, it is not properly constituted," a concept that is itself only on the verge of meaning, lacking precision and nuance, and reproducing the impossible position of belonging nowhere. More vehemently, Abdel-Rahman denounced the label which he considered to be an "insult," demanding that officials should recognize the country Palestine - from which he originates (40-year-old born in Saudi Arabia; interview, UK, 2013). The right to be recognized as originating from a country or a state - rather than being denied such an origin - therefore emerged as an essential, even existential, matter, with the denomination of statelessness being considered to be a form of epistemic violence.

In effect, without the re-definition of the concept to "mean that we are not on our land" as proposed by Mahmoud ( op cit), Nora considered that the label 'stateless' is itself a form of aggression since it denies a legitimate belonging to a particular space:

As I became politically aware, I understood that I am stateless... but it's not a term we speak about, like 'it's my identity, I am stateless.' ... It confiscates something from you, takes something from you by force. The whole terminology is imposed on you. I think it's very aggressive as a term...It contains a lot of aggression. It reflects the aggression that's coming from outside onto me, as my legal status, as being Palestinian, as having my passport, as not having the power to move... it's... maybe the title of this aggression can be this statelessness.

34-year-old born in Nablus. Interview, France, 2012. Emphasis added

Even when she recognises that she and other Palestinians are stateless legally and politically speaking, Nora does not personally or politically identify with this concept; 
Pre-publication version of article accepted for publication in the Journal of Ethnic and Racial Studies (2016)

rather, she feels that the label has been "imposed" upon her as an extension of the aggression that permeates her life. In this way, the label itself "confiscates" her ability to define herself or define what is present and absent in her life, concluding with a dialectical understanding of the relationship between statelessness and aggression.

Repeatedly, this concept and label - officially designated to reflect the vulnerability of those who do not have the right to have rights - was identified as reproducing, rather than resolving, the invisibility, marginalisation and exclusion of Palestinians, effectively denying their very existence:

For me there is no stateless [person]. It doesn't mean anything. It's like you are in front of me and I say you don't exist... But ignoring somebody doesn't mean he's not here. He's there. You are ignoring him but he's there.

64-year-old man born in Selet al-Dahar. Interview, France, 2012. Emphasis added

The rejection of this term, and the exclusionary processes which it is perceived to reproduce rather than challenge, were also expanded upon by Razak, who highlighted the possible implications of adopting the statelessness label even on an individual level:

[Stateless is] a term that affects dignity... If there comes a time when I can apply [for apatride status] I won't do it. It's so individualized...there is no collective notion behind it... We have a collective cause, not a cause that pertains to individuals... The individualization of the cause bothers me, because it's a collective cause and individual cause, in both directions at the same time... You can't separate them and you can't individualize this cause.

33-year-old born in Bethlehem. Interview, France, 2012

Being aware of the possibility of applying for apatride status via France's established statelessness determination procedure, Razak challenged the desirability of being legally recognised as a stateless person, reflecting the fear that when individual Palestinians are granted stateless status and are one step closer to being granted nationality, the possibility of achieving a meaningful collective solution becomes increasingly distant.

\section{STATELESS FROM A DISTANCE}

Importantly, interviewees repeatedly demonstrated that their awareness of the concept of statelessness, and of 'being' (or being considered by others to 'be') stateless had emerged from a geographical distance. In particular, this awareness arose through their own and others' interactions with diverse institutions and administrative procedures, including immigration officers and when applying for asylum, but also when registering with educational establishments. A key distinction emerging in this regard is the extent to which statelessness was imposed by others as a nationality marker (rather than as a legal status preceding the granting of a nationality), in contrast with the process of consciously applying for apatride status as a means of securing protection in Europe. As noted above, such processes are well-established in countries like France, with its Office Francais de Protection des Réfugiés et Apatrides (OFPRA), while countries such as the United Kingdom have only more recently introduced a formal statelessness determination 
Pre-publication version of article accepted for publication in the Journal of Ethnic and Racial Studies (2016)

process (April 2013), even when the label as a marker of 'nationality' - even if not of protection - had existed long before then.

In light of the increasing number of countries adopting statelessness determination procedures as a means of facilitating the 'identification' of stateless people, this distinction is highly significant since many Palestinians rejected being labelled as stateless through diverse administrative procedures. While perceived to be a first step in 'resolving' statelessness, 'becoming' a 'stateless' person in the European diaspora through such a process of administrative interpellation has itself been experienced as a form of "erasure" and even "aggression" (op cit). This discussion therefore demonstrates the disjuncture which exists between the ways in which the label 'stateless' is conceptualised by academics, practitioners and policy makers on the one hand, and by those individuals and groups who are labelled as such by others. This is the ultimate paradox of a policy framework which has ostensibly been designed to redress the lack of the right to have rights, which was perceived by many of the research participants, including Reema, as erasing their very existence:

I'm not 'stateless' [uses the English term]... I have my 'state.' For me, personally, I'm not like that. But in the eyes of others, I am... I have a friend who was in Norway. She had her residency permit, and [next to the category] 'state,' [there were] some asterisks, and then the word 'stateless.' On Facebook, she said: 'Well, I'm stateless...' It's sad, but it's sad for that state [Norway], that doesn't recognize something that exists... if you consider us 'stateless' [uses English word], too bad for you. We exist.

25-year-old born in Ramallah. Interview, France, 2012. Emphasis added

This is not to argue that Palestinians are not 'stateless' in either the juridical or political sense (as lacking a nationality or lacking an internationally recognised state), but rather to illustrate the need for a more nuanced engagement with the multiple meanings which this concept has for different stakeholders, including those whose disenfranchisement could be perceived to be magnified rather than overcome in Europe and further afield.

In spite of their embodied experiences of marginalisation, discrimination and de jure statelessness in the Middle East, the administrative, and political, steps of replacing individuals' Palestinian identity with the 'nationality' marker of XXA (the code for statelessness) in Europe was a traumatic event for a number of interviewees. In particular, Fatima, a woman in her 60s born in Galilee, offered a poignant account of the process of 'becoming' stateless in the diaspora, differentiating between her experiences of being brought up in Shatila refugee camp in Lebanon and her arrival in the UK (interview, UK, 2013). With reference to her childhood in Lebanon, she clarified that "I did not feel stateless. Or without an identity. I always felt I have an identity." That identity was one with which she self-identified: "I I am a refugee here and one day we will go to Palestine'. We were very enthusiastic, very hopeful... So I did not feel I was stateless." In direct contrast, she recalled the moment in which she was first categorised by the British authorities as a stateless person: 
Pre-publication version of article accepted for publication in the Journal of Ethnic and Racial Studies (2016)

When I went to register with the [British] police, they gave me that blue book... and they had written [her full name] and then [... for] nationality they put stateless... It blew me over: How come I am stateless? I went outside the police station and I was standing by the staircase and thinking what to do. Argue with that policeman? What do they mean by stateless? I have a state....

It was at that instant that, for "the first time I felt I was stateless. I felt very bad. 'Stateless' means someone who is not recognised, someone who is lost, someone up in the air... It means unfairness, injustice. It is inhuman.” The disbelief of being labelled stateless was overtaken by the emotional anguish of being denied not only her history, her identity and her sense of belonging to Palestine, but her very humanity, all within the country where she was seeking sanctuary.

The grief characterizing the process of 'becoming' stateless in the UK was paralleled in Rana's emotional account of having her Palestinian identity "erased" by the administration when she enrolled in a French university in 1982. At this point, her identity was documented as 'stateless' since "they didn't find the code for Palestine," and she was not Lebanese (also Boulatta 1998). In spite of Rana asking for her documents to identify her as a 'refugee' - on the basis that "at least [if they write] 'Palestinian refugee,' there is the word 'Palestine' in it" - it was only recently that her identity card had been marked "stateless of Palestinian origin", ensuring that "the Palestinian is there, you can't erase that..." (interview, France, 2012). Redefining statelessness in relation to the connection to Palestine, as demanded by Mahmoud ( op cit), ensured the reconstitution of Rana's place in the world.

These personal experiences of being forcibly labelled as stateless, of statelessness being imposed as a key identity marker, were also experienced by Issa on the border between the United States and Canada, where he - like Fatima in the UK - applied for asylum to receive international protection as a refugee: while having never heard this term before, Issa laughingly noted that statelessness "became my identity" from that moment onwards (50-year-old born in a refugee camp in Syria. Interview, UK, 2013). Having been a Palestinian refugee in Syria, he, like Fatima and Rana, was not only demoted from the status of 'the refugee' to that of an asylum-seeker by virtue of being outside of the Middle East (through a process of what Qasmiyeh refers to as a "reverse metamorphosis"), ${ }^{\text {vii }}$ but also stripped of his claims to a national identity and interpellated as a stateless person.

Given the hierarchy of rights that exist for refugees and stateless persons, it is notable that being identified and categorised as a stateless person offers fewer legal rights than refugee status (UNHCR 2014:31). In France, in particular, the decision of whether to apply for refugee status or apatride status emerged as a defining moment solidifying individuals' awareness of the concept of statelessness. For instance, Mahmoud indicated that statelessness is not an organic part of lived identity, but rather an identity marker which becomes salient as a result of having to navigate specific immigration and asylum procedures: "It is only when one has to engage with those people or when one wants to mention to a person who has proceeded with the application to ask for the apatride status 
Pre-publication version of article accepted for publication in the Journal of Ethnic and Racial Studies (2016)

or political refugee or another [status], but [otherwise, the term stateless] doesn't just pop up in a discussion..." (26-year-old born in Algeria; interview, France, 2012). In turn, Rajab also highlighted the pragmatic, legal meaning of this concept through reference to OFPRA:

the first time that it had a practical meaning for me was with Palestinian refugee friends who had applied for stateless status ('demande d'apatridie'). That's when I understood that there was a difference between stateless ('apatride') and asylum seeker.

31-year-old born in a refugee camp in Jordan. Interview, France, 2012

Throughout these interviews, references were repeatedly made of Palestinian refugees (recognized as such in the Middle East) becoming asylum-seekers or applying for stateless status in France or the UK. On a practical level, the geographies of status and of identity come to the fore, with particular status and identity markers being associated with particular spaces: while Palestinians are thus recognized as 'Palestine refugees' within UNRWA's five areas of operation in the Middle East (Lebanon, Jordan, Syria, Gaza and the West Bank), their refugee status is not automatically recognized by European states. Instead, they become stateless asylum-seekers whose ability to access protection in the global North has habitually been undermined due to a mis-application of international law (as discussed above).

Although many interviewees thus not only lacked a personal or political identification with the term stateless, other labels and categories were repeatedly asserted, including the labels of refugee and exile in particular. While acknowledging the concept of statelessness, Miriyam stressed that "in the Palestinian context we have other terms that are more common [...] Exile, diaspora, refugee..." (interview, France, 2012; emphasis added). In direct contrast with the personal distancing from the notion of statelessness outlined above, many interviewees thus reiterated their ongoing identification with the refugeeness they had borne since birth, even if they were, de jure, citizens:

On the one hand I am not [apatride]... juridically... I am French so... I have one [patrie]. I have at least one... even with regard to the Palestinian side I don't consider myself apatride...because we have a homeland (patrie) and so...I consider myself...I define myself as a refugee, an exile but not as an apatride.

25-year-old born in France. Interview, France, 2012. Emphasis added

Equally, Saif indicated that, having been naturalised as a Swedish citizen, "my Swedish passport means lot to me as a refugee" (interview, Sweden, 2014; emphasis added). Just as Sanbar refers to the intergenerational inheritance of the archival memory of and commitment to Palestine - "Palestine travelling around on the shoulders of its children" (Sanbar 2001:91) - so too does their refugeeness 'travel' across not only time and space, but also across legal statuses. ${ }^{\text {vii }}$

In effect, as Qasmiyeh (cited in Qasmiyeh and Fiddian-Qasmiyeh 2013:138) has argued elsewhere, 
Pre-publication version of article accepted for publication in the Journal of Ethnic and Racial Studies (2016)

becoming a [British] citizen does not exclude or erase the fact that I was born a refugee. On the contrary, it is particularly vital for me to remain in contact with my history, or perhaps histories, of refugeeness, and the reality that the majority of my family are still refugees, and are still inhabitants of different refugee camps in Lebanon. How can a son or a brother be a citizen while the rest of his family are refugees elsewhere? It is that personal, familial linkage which allows you to respond to that history with knowledge and acceptance of the fact that you are part of a group. It is not a tribalistic linkage, and yet as a result of being part of that place, of that upbringing, your citizenship does not cancel out the refugeeness of the other (which is simultaneously part of yourself).

The overlapping refugeeness of citizens - itself an existential and political declaration of belonging to the collective whose status remains pending even when individual security has been obtained on a legal level - clearly resonates with the significance of the relationship between individual and collective statelessness, and demonstrates the ongoing connections between Palestinian people and places on inter-generational and transnational levels alike.

\section{CONCLUSION}

In the context of ever-changing statuses across diverse geographies, which often reflect a 'demotion' from one label and legal status to another, ambivalence towards or resistance to 'the stateless label' is not a rejection of individual claims to rights and protection, but rather a rejection of a series of processes which reinscribe, rather than redress, the absence of a demarcated geographical compass. Ultimately, the label 'stateless' is not perceived as offering protection, but potentially as erasing existing identity markers and forms of attachment, and, indeed, of negating the right to self-determination itself, as a collective right which would provide both collective and individual remedy to disenfranchisement and erasure.

The constellation of labels inscribed by Others and/or embraced by Palestinians, whether in isolation or as integral components of hyphenated identities, echo the multiple geographies of exclusion and belonging underpinning the (counter)narratives of statelessness examined in this article. In spite of (or precisely due to) the acquisition and imposition of new bureaucratic labels and the concomitant erasure of meaningful signifiers at international borders, in police stations, immigration centres and universities, interviewees have simultaneously reasserted and transcended the erasure of a single root (Palestine); they have asserted their multiple origins through their intergenerational commitment to the Palestinian homeland of the past, present and future, their 'travelling fear' of the European host states and states of nationality which simultaneously welcome and reject them through processes of hostipitality, and a transnational longing for the Middle Eastern refugee camps which are condensed spaces of marginalisation, liminality and identity (Qasmiyeh and Fiddian-Qasmiyeh 2013). The archives of knowledge and identity drawn upon to negotiate these and other labels and spaces, during transitions across borders and within thresholds (Derrida 1996; Boulatta 1998; Sanbar 2001), have been both embodied and inherited, and yet they remain contested and ambiguous, a matter both of existence and of the existential. 
Pre-publication version of article accepted for publication in the Journal of Ethnic and Racial Studies (2016)

\section{REFERENCES}

Arendt, Hannah. 1951/1973. The Origin of Totalitarianism. New York: Harcourt.

Boullata, Issa. 1998. "Jerusalem: The Archaeology of Memory." Jusoor, 9-10:36.

Derrida, Jacques. 2000. "Hostipitality.” Angelaki, 5(3):3-18.

Derrida, Jacques. 1996. Archive Fever. Chicago: Chicago University Press.

Edwards, Alice and Laura Van Waas. 2014. "Statelessness". In The Oxford Handbook of Refugee and Forced Migration Studies, edited by E. Fiddian-Qasmiyeh, G. Loescher, K. Long and N. Sigona, 290-301. Oxford: Oxford University Press.

Fiddian-Qasmiyeh, Elena. 2013. "The Intergenerational Politics of 'Travelling Memories': Sahrawi refugee youth remembering home-land and home-camp." Journal of Intercultural Studies, 34(6):631-649.

Fiddian-Qasmiyeh, Elena. 2014. 'Reconceptualising Statelessness: Palestinian and Kurdish narratives and experiences,' paper presented at The Global Forum on Statelessness, The Hague, Sep.2014.

Fiddian-Qasmiyeh, Elena. 2015. South-South Educational Migration, Humanitarianism and Development. Oxford: Routledge.

Gupte, Jaideep and Lyla Mehta (2007) "Disjunctures in Labelling Refugees and Oustees." In The Power of Labelling: How People are Categorized and Why It Matters, edited by J. Moncrieffe and R. Eyben, 64-79. London: Routledge.

Human Rights Watch. 2010. Stateless Again: Palestinian-Origin Jordanians Deprived of their Nationality. HRW.

Institute of Statelessness and Inclusion. 2014. The World's Stateless. ISI.

Kibreab, Gaim. 1999. "Revisiting the Debate on People, Place, Identity, and Displacement." Journal of Refugee Studies, 12(4):384-428.

Kumsa, Martha K. 2006. “"No! I'm Not a Refugee!' The Poetics of Be-Longing among Young Oromos in Toronto.” Journal of Refugee Studies, 19(2):230-255.

Larson, Nina. 2014. 'UN aims to eliminate statelessness within 10 years.' Agence France Press, 3 November 2014.

Ludwig, Bernadette. 2013. "'Wiping the Refugee Dust from My Feet': Advantages and Burdens of Refugee Status and the Refugee Label.” International Migration, DOI: 10.1111/imig.12111.

Malkki, Lisa. 1992. "National Geographic: the Rooting of Peoples and the Territorialization of National Identity among Scholars and Refugees." Cultural Anthropology, 7(1):24-44.

Manly, Mark and Laura Van Waas. 2014. "The State of Statelessness Research." Tilburg Law Review, 19(1-2):3-10.

Molavi, Shourideh. C. 2013. Stateless Citizenship: The Palestinian-Arab Citizens of Israel. Leiden: Brill.

Peteet, Julie M. 1995. "Transforming Trust: Dispossession and Empowerment among Palestinian Refugees." In Mistrusting Refugees, edited by V.E. Daniel and J.C. Knudsen, 168-186. Berkley: University of California Press.

Qasmiyeh, Yousif M. (2014) 'Thresholds.' Critical Quarterly, 56(4):67-70.

Qasmiyeh, Yousif M. and Elena Fiddian-Qasmiyeh (2013) "Refugee Camps and Cities in Conversation." In Migration and Religious Identity in the Modern Metropolis, edited by J. Garnett and A. Harris, 131-143. Farnham: Ashgate. 
Pre-publication version of article accepted for publication in the Journal of Ethnic and Racial Studies (2016)

Rancière, Jacques. 2004. 'Who is the Subject of the Rights of Man,' The South Atlantic Quarterly 103(2/3):297-310.

Redclift, Victoria. 2013. Statelessness and Citizenship. London: Routledge.

Sa'di, Ahmad H. and Lila Abu-Lughod. 1997. Nakba: Palestine, 1948 and the Claims of Memory. New York: Columbia University Press.

Said, Edward.W. 1983. The World, the Text, and the Critic. London: Vintage.

Sanbar, Elias. 2001. "Out of Place, Out of Time." Mediterranean Historical Review 16(1):87-94.

Shiblak, Abbas. 2011. “Arabia's Bidoon.” In Statelessness and Citizenship, edited by B.K. Blitz and M. Lynch, 172-193. Cheltenham: Edward Elgar.

Staples, Kelly. 2012. Retheorising Statelessness. Edinburgh: Edinburgh University Press. Suleiman, Yasir. 2016. Being Palestinian: Personal Reflections on Palestinian Identity in the Diaspora. Edinburgh: Edinburgh University Press.

UNHCR. 2014. Handbook on Protection of Stateless Persons. Geneva: UNHCR.

Vali, Abbas. 1998. "The Kurds and their "Others"." Comparative Studies of South Asia, Africa and the Middle East, 18(2):82-95.

Van Waas, Laura. 2008. Nationality Matters: Statelessness Under International Law. The Hague: Intersentia.

Vighi, Fabio, Alexis Nuselovici and Mauro Ponzi. 2014. "Introduction." In Between Urban Topographies and Political Spaces: Threshold Experiences, edited by F. Vighi, A. Nuselovici and M. Ponzi, vii-x. Plymouth: Lexington Books.

Zetter, Roger. 1991. "Labelling refugees: Forming and transforming a bureaucratic identity." Journal of Refugee Studies, 4(1):39-62.

Zetter, Roger. 2007. "More Labels, Fewer Refugees: Remaking the Refugee Label in an Era of Globalization.” Journal of Refugee Studies, 20(2):172-192.

\footnotetext{
${ }^{i}$ Thanks are due to Nell Gabiam, Barzoo Eliassi and Paladia Ziss for their research assistance in France, Sweden, and the UK respectively, and to Yousif M. Qasmiyeh for his critical feedback on earlier versions of this paper.

ii See UN General Assembly Resolutions 2535, 2649, 3236, 43/177, 48/94 passed in 1969, 1970, 1974, 1988 and 1993 respectively, and the International Court of Justice Advisory Opinion of 2004 asserting that "Israel is bound to comply with its obligation to respect the right of the Palestinian people to selfdetermination."

iii This is the legal situation, in particular, of over one million Palestinians in Lebanon and - before the outbreak of the civil war - in Syria (ISI 2014:129).

${ }^{\text {iv }}$ Following the title of Van Waas's key study (2008).

${ }^{v}$ On the multiple meanings and memories of the Palestinian homeland, see the edited collections by Sa'di and Abu-Lughod (2007) and Suleiman (2016).

${ }^{\mathrm{vi}}$ This association is facilitated by the French for statelessness (apatridie), which centalises not the absence of a 'state', as in English, but the absence of the patrie - from the Latin patria - the homeland (or more accurately, the father-land) from which the Palestinians have been displaced, dispossessed, and ultimately absented (on the latter, see Sanbar, 2001:87, 92). Nonetheless, the equation of statelessness with the absence of the homeland also emerged during interviews conducted in English and in Swedish.

vii This term denotes the inversion of the 'paradigmatic' metamorphosis of the persecuted citizen who applies for asylum in order to be granted international protection as a refugee. (Personal communication, 2013).

viii In many ways, this contradicts Peteet's homogenising assertion that 'Palestinians in Lebanon' reject the label 'refugees' (laje'een), preferring the term 'the returners' (al-a'ideen -a term which can more accurately be translated as 'returnees') in the region (1995:177). Rather, even the meaning of the 'refugee' status granted in the EU was contested by a small number of interviewees who had described themselves as
} 
Pre-publication version of article accepted for publication in the Journal of Ethnic and Racial Studies (2016)

refugees within the context of the Middle East, including Nabila who was officially recognised as a stateless person in France, but rejected being identified as a "political refugee": "the fact that I am Palestinian that's political but I didn't come to France as a political refugee... and between 'political refugee' and 'apatride,' I prefer apatride. Because we didn't choose politics, politics chose us...it's something that is imposed upon us." (55-year-old born in a refugee camp in Lebanon. Interview, France, 2012.) 